\title{
Combi-protein coated microcrystals of lipases for production of biodiesel from oil from spent coffee grounds
}

\author{
Aditi Banerjee', Veena Singh ${ }^{2}$, Kusum Solanki ${ }^{3}$, Joyeeta Mukherjee ${ }^{2}$ and Munishwar Nath Gupta ${ }^{4^{*}}$
}

\begin{abstract}
Background: Replacing chemical catalysts with biocatalysts is a widely recognized goal of white biotechnology. For biocatalytic processes requiring low water containing media, enzymes for example commercial preparations of lipases, show low catalytic efficiencies. Some high activity preparations for addressing this concern have been described. Protein coated microcrystals (PCMC) constitute one such preparation. The present work describes a Combi-PCMC for synthesis of biodiesel from the oil extracted from spent coffee grounds.

Results: Different lipases were screened for biodiesel synthesis from crude coffee oil out of which Novozym 435 gave the best conversion of $60 \%$ in $4 \mathrm{~h}$. Optimization of reaction conditions i.e. \% water, temperature and purification of coffee oil further enhanced conversion upto $88 \%$ in 24 h. A mixture of Novozym 435 and a cheap commercially available 1,3-specific lipase RMIM (from Mucor miehei) was used in different ratios and 1:1 was found to be the best trade-off between conversion and cost. The commercial preparations then were replaced by a novel biocatalyst design called Combi-Protein coated microcrystals (Combi-PCMC) wherein CAL B and Palatase were co-immobilized with $\mathrm{K}_{2} \mathrm{SO}_{4}$ as the core and this performed equivalent to the commercial preparations giving $83 \%$ conversion in $48 \mathrm{~h}$.

Conclusion: Coffee oil extracted from spent coffee grounds could be used for the synthesis of biodiesel by using appropriate commercial preparations of lipases. The expensive commercially immobilized preparations can also be replaced by a simpler and inexpensive immobilization design called combi-PCMC which synergizes the catalytic action of a nonspecific lipase CAL B and a free form of 1,3-specific lipase from Mucor miehei.
\end{abstract}

Keywords: Biodiesel, Protein coated microcrystals, Coffee oil, Lipases, Transesterification

\section{Background}

Lipases constitute the most frequently used enzyme in industrial enzymology [1-3]. Many industrial preparations are available commercially from several vendors. This ready availability of such preparations is largely due to early industrial application of lipases in fat splitting [4]. In recent years, lipases have also been used in low water containing organic media for esterification/ transesterification reactions [5,6]. In general "straight from the vendor" and lyophilized powders show poor catalytic activity in such media. This is due to the structural changes in the enzyme molecules which take

\footnotetext{
* Correspondence: appliedbiocat@yahoo.co.in

${ }^{4}$ Department of Biochemical Engineering and Biotechnology, Indian Institute of Technology Delhi, Hauz Khas, New Delhi 110016, India

Full list of author information is available at the end of the article
}

place during the drying process $[7,8]$. However, crystallization and precipitation have been found out to be better option for "drying" enzymes for use in low water media [9-16]. One such approach is preparation of protein coated microcrystals $[10,14]$. In this biocatalyst design, enzyme gets precipitated over microcrystals of salts or amino acids or sugar molecules. Fairly high initial rates for catalysis in low water containing organic media have been obtained for PCMCs of horse radish peroxidase (HRP), soybean peroxidase (SBP), horse liver alcohol dehydrogenase (HLADH), catalase and lipases [16]. For example, PCMC of lipase from Candida antarctica (CAL B) and Rhizomucor miehei (Palatase) showed a 5 and 15 fold increase in catalytic rates as compared to "straight from the vendor" preparations in the kinetic resolution of phenyl ethanol [10].

\section{() Chemistry Central}


Major applications of lipases involve biotransformations involving fats and oils. In the context of such reactions, lipase can be classified either as 1, 3 specific (preferentially attacking 1 and 3 position on the triglycerides) or nonspecific (showing no preference to either 1 or 2 or 3 positions on the triglycerides). The choice of lipases, for example, during production of biodiesel, is largely governed by cost of lipase and its above mentioned specificity.

The present work involves preparation of combi-PCMCs of two different lipases for preparation of biodiesel starting with the oil obtained from spent coffee grounds. The two component lipases were palatase (lipase from Rhizomucor miehei in free form) and CAL B (lipase from Candida antarctica, also in free form). CAL B has been found to be a non-specific lipase when used for biodiesel formation [17]. On the other hand, Rhizomucor miehei lipase is known to be a 1,3-specific enzyme [18].

The global shortage of fossil fuels and environmental concerns has sustained the interest in biodiesel production [19-30]. Biodiesel is a mixture of esters of long chain fatty acids and short chain monohydric alcohols $(\mathrm{MeOH}$ or $\mathrm{EtOH})$. Biodiesel can be obtained from plant oils which constitute renewable resources. Biodiesel is biodegradable and its use (in place of diesel) leads to lower engine exhaust emissions of particulate matter and green house gases such as $\mathrm{CO}, \mathrm{CO}_{2}$ and $\mathrm{SO}_{\mathrm{x}}[24,30]$.

After the initial enthusiasm, there have been some concerns about the overall sustainability (of biodiesel production) as well as the diversion of the land (which could have been used for growing food crops) to growing energy crops [31]. With regard to the latter context; using feed stock which is a waste material seems to be the most attractive idea. Such an approach solves the waste disposal problem and simultaneously yields a valuable product. The use of spent restaurant grease/oils for producing biodiesel has been one such approach [32-34].

Few years back, oil obtained from spent coffee grounds (the material which is left after the brewed coffee liquor is used for drinking) has been shown to be a viable source for preparing biodiesel $[35,36]$. Recently, Calixto et al. have used supercritical methanol to carry out in situ extraction and transesterification of spent coffee ground oil to obtain biodiesel [37].

It has been pointed out that spent coffee grounds contain 10-15 weight \% oil [38]. With the global coffee production quoted as 16.34 billion pounds per year [35], spent coffee grounds constitute a huge amount of waste material. With chains of cafés exclusively devoted to serving coffee, the working model could be similar to the one adopted for collecting restaurant grease for producing biodiesel [32-34].

Biodiesel is a mixture of monoalkyl esters of fatty acids and is obtained by the transesterification of oils/fats. The transesterification can be catalyzed by either an acid or alkali or by an enzyme. When an enzyme is used as a catalyst, the reaction can be carried out at a moderate temperature; downstream processing is easier and if the feedstock oil contains high FFA content, enzymatic process seems to be more robust to deal with it [19-25]. Lipases have been used for this purpose and the process has been described with a very large number of oils and fats with varying degree of success [39-46].

Transesterification reactions catalyzed by lipases are carried out in a low water media $[47,48]$. Either one can use nearly anhydrous organic solvents as reaction medium or work with a solvent free media in which case substrates (oil and the alcohol) constitute the reaction medium $[20,42,45]$.

The present work shows that enzymatic transesterification does work fairly well with the relatively new and promising feedstock of spent coffee grounds. The catalysis could be carried out by employing a mixture of two commercially available immobilized preparations of two lipases. It was also shown that a new biocatalyst design called Combi-PCMC (combined protein coated micro crystals) could replace the above enzyme preparations as a less expensive alternative.

\section{Results and discussion \\ Extraction of coffee oil}

It has been reported that on an average spent coffee grounds yield about $11-20 \%$ oil [49]. For oil extraction, simple hexane extraction under reflux conditions gave only $6 \%$ coffee oil. However when the hexane extraction was done in the soxhlet apparatus, the yield of coffee oil obtained was $14 \%$. Three phase partitioning [50] using tert-butanol was also performed, which resulted in a $4 \%$ coffee oil recovery. It was decided to use the soxhlet method for obtaining the coffee oil in the present work.

\section{Screening of lipases for biodiesel preparation from crude coffee oil}

Figure 1 shows the result of screening of 9 different commercial preparations of lipases for their transesterification efficiency in catalyzing the conversion of coffee oil to ethyl esters of the fatty acids. Lipases from different sources vary widely in the range of their substrate specificities $[3,6]$. Industrial preparations of various lipases are commercially available because of their numerous industrial applications [1]. The reaction mixture consisted of coffee oil $(0.5 \mathrm{~g})$ and ethanol $(126 \mu \mathrm{l})$ (molar ratio of oil: ethanol was 1:4). The ratio of the oil: ethanol was chosen in view of the results reported by earlier workers [23,42-44]. Slight stoichiometric excess of alcohol has been reported to be required for obtaining satisfactory transesterification [23]. At the same time, excess of alcohols (especially lower chain alcohols which are used for producing biodiesel) 


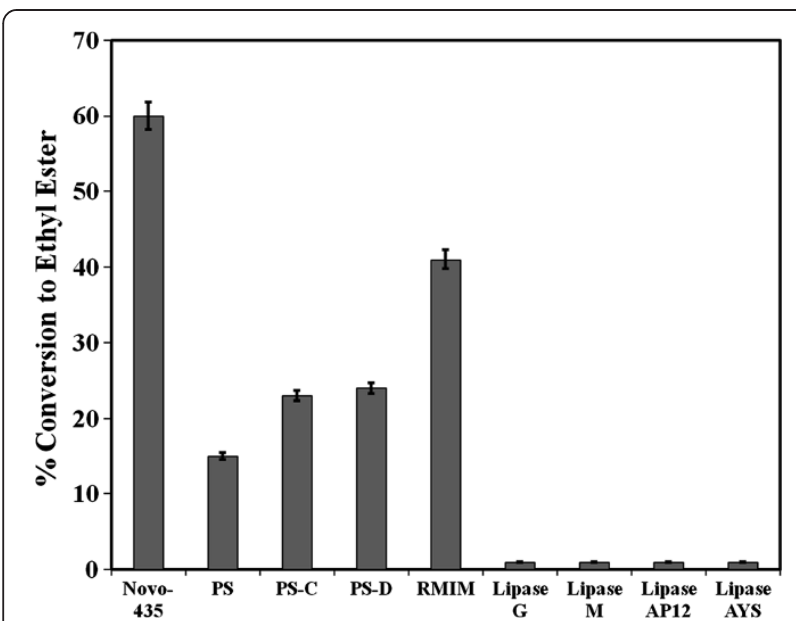

Figure 1 Screening of lipases. Crude coffee oil $(0.5 \mathrm{~g})$ and ethanol were taken in the molar ratio of 1:4. 10\% (w/w of oil) different "straight from the bottle" lipases were added. Aliquots were taken out after $4 \mathrm{~h}$ and analyzed by GC as described in materials and methods section. The experiments were done in duplicates and the error between the two sets was within 3\%. Lipases are abbreviated as follows: lipase from Pseudomonas cepacia: PS, PS C (lipase immobilized on ceramic particle), PS D (lipase immobilized on diatomaceous earth), Lipase from Candida rugosa: lipase AYS; immobilized form of lipase from CAL B: Novo-435, Rhizomucor miehei lipase immobilized on macroporous anion exchange resin: RMIM; Lipase from Mucor javanicus: Lipase M; Lipase from Aspergillus niger: Lipase AP12; Lipase from Penicillium camemberti: Lipase G.

generally inactivate the enzymes [23]. In view of this, mostly 1:4 has been the ideal choice. Other screening conditions were also similar to those used earlier in our laboratory [43]. The ester content (weight \%) was determined after $4 \mathrm{~h}$. Amongst all the lipases; Novozym 435 was found to be the best biocatalyst preparation as it gave highest conversion to the esters.

\section{Effect of water content on biodiesel production}

Amount of water present or more strictly water activity $\mathrm{a}_{\mathrm{w}}$ of the reaction medium is known to be an important parameter which influences reaction rates/conversions in enzyme catalyzed reactions in low water media [5,51]. As mentioned elsewhere $[23,43]$, in processes like biodiesel production, the ultimate process is intended to be carried out at a large scale, so it makes sense to optimize the process in terms of added water amount. The effect of water content on the transesterification reaction of coffee oil with ethanol under solvent free conditions using Novozym 435 (10\% w/w of oil) was examined by carrying out the reaction at five different water contents: $0,1,2,3$ and $10 \%$ (w/w of enzyme). Figure 2 shows the effect of different amounts of water added to the reaction mixture on biodiesel production. After $4 \mathrm{~h}$, it was observed that the highest ester yield (60\%) was obtained when no water was externally added to the reaction

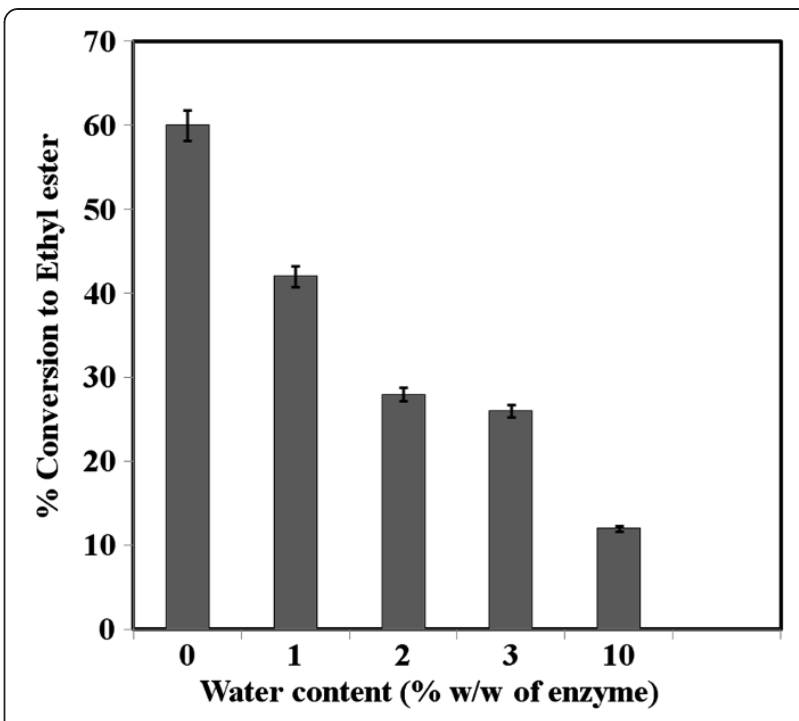

Figure 2 Effect of water content. Crude coffee oil $(0.5 \mathrm{~g})$ and ethanol were taken in the ratio of 1:4 ( $\mathrm{mol} / \mathrm{mol}) .10 \%$ (w/w of oil) Novozym 435 was added. Different amounts of water (w/w of enzyme) were added to the reaction media. Aliquots were taken out after $4 \mathrm{~h}$ and analyzed by GC as described in materials and methods section. The experiments were done in duplicates and the error between the two sets was within $3 \%$.

mixture. So, for all the further transesterification reactions, no water was added in the reaction mixture.

\section{Effect of temperature on biodiesel preparation}

The effect of temperature on the transesterification reaction of coffee oil with ethanol under solvent free conditions using Novozym 435 (10\% wt of oil) was examined by carrying out the reaction at three different temperatures: 40,50 and $60^{\circ} \mathrm{C}$ (Figure 3). The maximum ester content obtained was $88 \%(\mathrm{w} / \mathrm{w})$ at $8 \mathrm{~h}$ at $40^{\circ} \mathrm{C}$. This was surprising as even CAL B, the free form of Novozym 435 is recommended by the vendor to be stable upto $60^{\circ} \mathrm{C}$ even in water. The enzymes generally are much more stable in low water media [47]. Pirozzi and Greco (2004) [52] have found Novozym 435 to work optimally at $70^{\circ} \mathrm{C}$ during synthesis of butyl lactate at $\mathrm{a}_{\mathrm{w}}=0.06$ [52]. The reason presumably may be due to greater inactivation at higher temperatures by other substances present in coffee oil. Also, as pointed out by Antczak et al. (2009) [23], optimum temperature for enzymatic transesterification can depend upon a complex interplay between enzyme stability, nature of medium and rate of transesterification [23].

\section{Effect of enzyme loading}

The cost of the enzyme is an important consideration in the overall process economics. It was seen that with $5 \%$ (w/w) enzyme, conversion to $70 \%$ esters was observed in $16 \mathrm{~h}$. continuing the reaction upto $24 \mathrm{~h}$ did not result in 


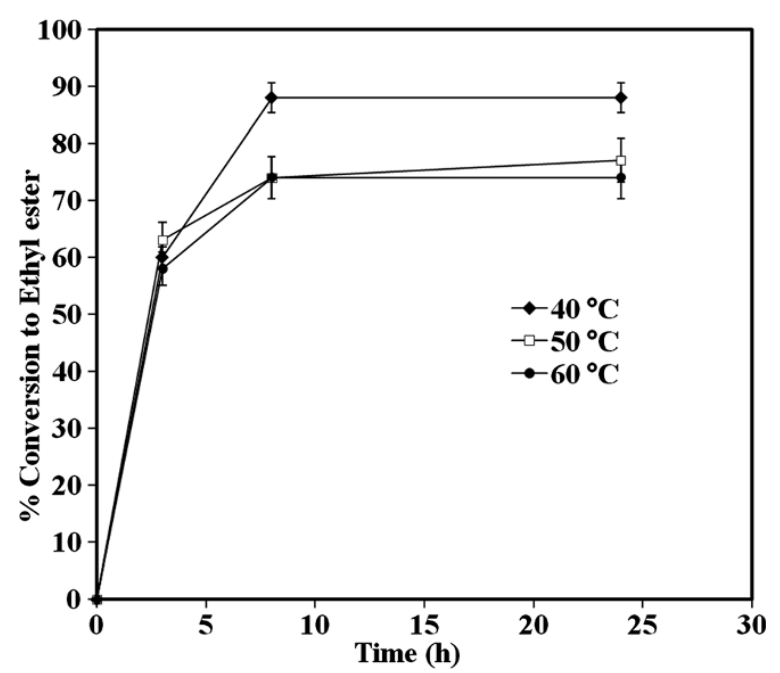

Figure 3 Effect of temperature. Crude coffee oil $(0.5 \mathrm{~g})$ and ethanol were taken in the molar ratio of 1:4. 10\% (w/w of oil) Novozym 435 lipase was added and incubated at different temperatures. Aliquots were taken out at regular intervals and analyzed by GC as described in materials and methods section. The experiments were done in duplicates and the error between the two sets was within $3 \%$.

any further conversion showing that the reaction had reached the equilibrium by $16 \mathrm{~h}$ (Additional file 1: Figure S1). As compared with $88 \%$ conversion with $10 \%(\mathrm{w} / \mathrm{w})$ enzyme in $8 \mathrm{~h}$ (Figure 3), this was less efficient. Hence, reducing the amount of enzyme was not desirable if one wanted to achieve the maximum possible ester content. Further optimization experiments were carried out by using $10 \%(\mathrm{w} / \mathrm{w})$ enzyme only.

Lipase catalysed biodiesel formation is controlled by a fairly complex set of parameters. The substrates, alcohol and the product glycerol are known to inhibit lipases [53-55]. In low water media, even water molecules act as enzyme inhibitors [56]. Apart from these complex inhibition patterns, lipases also undergo inactivation. Hence, while transesterification reactions are believed to be equilibrium controlled, in reality the final \% conversion is dependent upon the amount of enzyme used.

\section{Purification of the coffee oil}

Coffee oil is known to contain various low molecular weight substances [36]. This results in coffee oil (as extracted) becoming a dark brown colored liquid. The oil was decolorized by refluxing with $2 \mathrm{~g}$ activated charcoal for $1 \mathrm{~h}$. A comparison between the colored (crude) and decolorized (clean) oil was carried out to see if the polyphenols etc. present in the coffee oil had any effect on the percentage conversion to the ethyl ester.

\section{Enzyme screening with clean coffee oil}

The best five performing lipases identified after screening with the crude coffee oil, Novozym 435 (immobilized form of CAL B L), Pseudomonas cepacia (PS) lipase, PS C (lipase immobilized on ceramic particle), PS D (lipase immobilized on diatomaceous earth), Rhizomucour miehei lipase immobilized on macroporous anion exchange resin (Lipozyme RMIM) were again screened to check the production of biodiesel from clean coffee oil (Figure 4). This screen was based upon $24 \mathrm{~h}$ reaction time to get an estimate of the highest conversion obtainable (irrespective of the rate of the reaction) with a particular enzyme preparation. Novozym 435, which is known to give fairly high rates for the enzymatic transesterification reaction for biodiesel conversion with various oils $[25,57,58]$, again gave the highest conversion which was $88 \%$ in $24 \mathrm{~h}$ and the next best result was obtained with RMIM, which gave a conversion of $70 \%$ in $24 \mathrm{~h}$. RMIM is a 1,3-specific enzyme and thus its theoretical yield is expected to be $66 \%$. Yield higher than the theoretical yield may be due to a small amount of acyl-migration. Acyl-migration is a non-enzymatic process which involves spontaneous movement of an acyl-group from one hydroxyl group to an adjacent one $[59,60]$.

It was seen that on the whole, decolourization of coffee oil with activated charcoal did not have a significant effect on the enzyme activity. However, all further work was carried out with the clean coffee oil.

\section{Transesterification reaction with varying ratios of Novozym 435: RMIM}

Novozym 435 is a relatively more expensive form of the commercially available lipase preparation. It was observed during the enzyme screening that the next best enzyme for biodiesel formation was RMIM, which is an immobilized form of the enzyme Rhizomucor miehei.

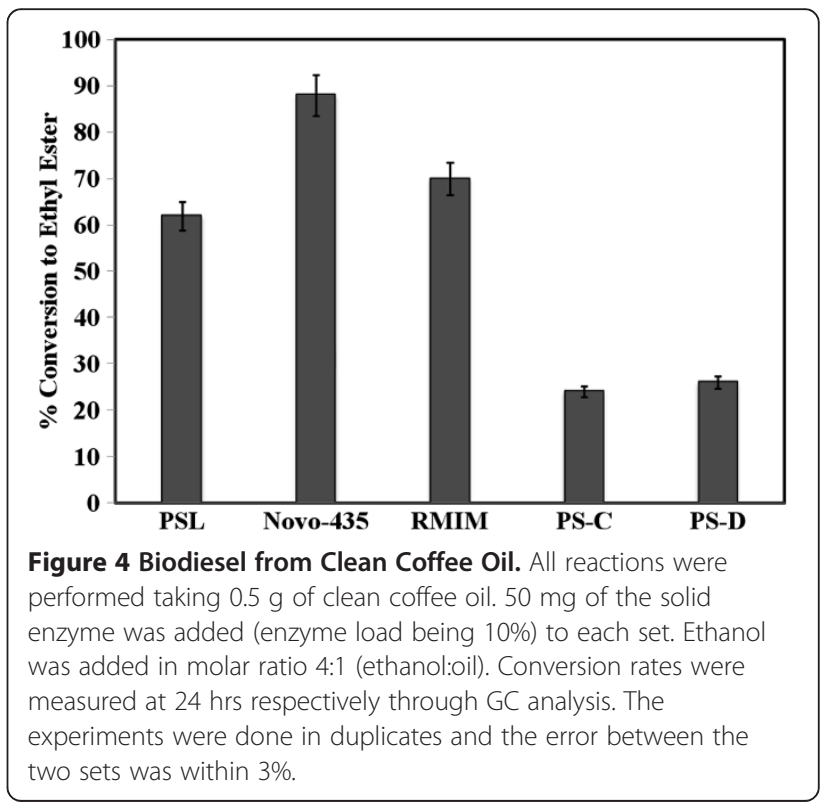


This is relatively less expensive. However, as it is a 1,3specific enzyme, some amount of Novozym 435 would be required for obtaining conversions beyond 66\%. The presence of Novozym 435 and RMIM together were expected to give high conversion rates. The triglyceride would be transesterified by the 1,3-specific lipase to give the 2-monoglyceride. The 2-monoglyceride can also be transesterified by the non-specific lipase (CAL B) to give the fatty acid ethyl ester and glycerol. Therefore different ratios of RMIM and Novozym 435 were tried.

Reactions were carried out wherein the ratio of Novozym 435 was gradually decreased. Initially reaction was performed taking Novozym 435 to RMIM in a 3:1 ratio (Figure 5). In this case the conversion obtained in 24 h was $85 \%$ which was quite comparable to what was observed for Novozyme-435 catalyzing the reaction alone. Next the ratio of Novozym 435 to RMIM was further varied to 1:1 (Figure 5) and the highest conversion obtained was $86 \%$ with the clean oil in $24 \mathrm{~h}$. When the ratio of Novozym 435 to RMIM was 1:3 (Figure 5) the conversion in $24 \mathrm{~h}$ was about $80 \%$ for the clean oil. Looking at the three different ratios of Novozym 435 to RMIM, we can say that the ratio of $1: 1$ constitutes the best "trade off" between cost and conversion. That is, replacing half the Novozym 435 of the reaction with RMIM which is cheaper enzyme, we would still get conversion that would be comparable to using Novozym 435 alone.

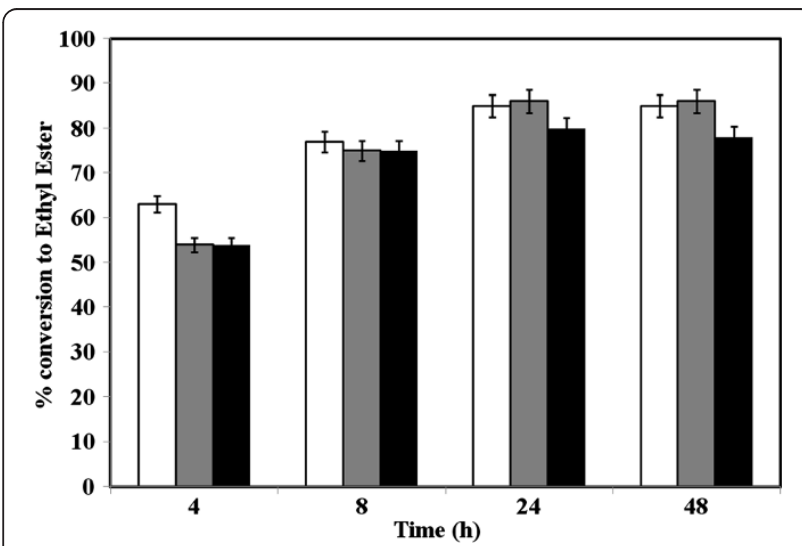

Figure 5 Biodiesel Conversion with Clean Oil using Novozym 435 + RMIM. Reactions were performed taking $0.5 \mathrm{~g}$ coffee oil. Ethanol was added in molar ratio 4:1 (ethanol: oil). Novozym $435+$ RMIM = 3:1 (White Bars); 37.5 mg of enzyme Novozym 435 (enzyme load being $7.5 \% \mathrm{w} / \mathrm{w}$ of oil) and $12.5 \mathrm{mg}$ of enzyme RMIM (enzyme load being $2.5 \% \mathrm{w} / \mathrm{w}$ of oil) was added. Novozym $435+\mathrm{RMIM}=1: 1$ (Grey Bars); 25 mg of enzyme Novozym 435 (enzyme load being 5\% w/w of oil) and $25 \mathrm{mg}$ of enzyme RMIM (enzyme load being 5\% w/ w of oil) was added. Novozym $435+$ RMIM = 1:3 (Black bars); 12.5 mg of enzyme Novozym 435 (enzyme load being 2.5\% w/w of oil) and $37.5 \mathrm{mg}$ of enzyme RMIM (enzyme load being $7.5 \% \mathrm{w} / \mathrm{w}$ of oil) was added.

\section{Designing inexpensive immobilized lipases for biodiesel synthesis}

While enzyme catalysed synthesis of biodiesel is considered the most desirable approach, the cost of the enzyme continues to be the major technological constraint in adoption of biocatalysis for production of this biofuel. In the last few decades, various approaches of immobilization of enzymes for obtaining high catalytic performance in low water media have been suggested [10,13,14,61-63]. One such enzyme design is protein coated micro crystals (PCMC) [10]. In this approach, a simple inexpensive salt like $\mathrm{K}_{2} \mathrm{SO}_{4}$ is used as the immobilization matrix and the enzyme is spread over the crystal surface. Fairly high initial rates have been reported with PCMC preparations [10]. PCMC of CAL B and Palatase showed a 5 and 15-fold increase in catalytic activity respectively as compared to the enzyme as received in the kinetic resolution of 1-phenylethanol [10]. Many other enzymes have also been tried by other workers and their PCMCs also showed marked enhancement in catalytic activity as compared to that of the corresponding forms as received from the vendor. Horse radish peroxidase (HRP), soybean peroxidase (SBP), horse liver alcohol dehydrogenase (HLADH) and catalase showed 18, 9, 50 and 25-fold increase respectively [16]. Earlier, PCMC of a lipase has been reported to work well for obtaining biodiesel from Madhuca indica oil [43]. For preparation of PCMCs, the free forms of the Novozym 435 [CAL B] and RMIM [Palatase] were used. These free forms are considerably less expensive than their immobilized preparations. Both CAL B and Palatase are available in liquid form. According to Schoevaart et al. (2003) [64], tert-butanol was a good solvent for precipitation of both CAL B and Palatase as complete activity could be recovered on precipitation. Therefore for preparation of PCMC and CLPCMC tert-butanol was used as organic solvent for precipitation. PCMC of CAL B gave a conversion of $66 \%$ in $48 \mathrm{hrs}$ with clean coffee oil (Figure 6). Expectedly the PCMC of Palatase gave less conversion to ethyl ester. In 48 hrs 58\% conversion was obtained (Figure 6). When PCMCs of CAL B and Palatase were mixed in the ratio of $1: 1$, the conversion of $65 \%$ (similar to what was obtained with PCMC of CAL B alone) in 48 hours was obtained (Figure 7). In this experiment (with mixture of PCMCs), the amount of individual PCMC taken was half of what was used when that PCMC was used alone. So, the \% conversions are comparable.

The synergy between two different enzymes by coimmobilization or mixing two immobilized preparations has been found to be successful in some cases $[65,66]$. Few years back, we reported combi-CLEA [67] and multipurpose CLEA [68] designs as further applications of this concept. For better synergy of CAL B and Palatase, a combi-PCMC was prepared wherein half the 


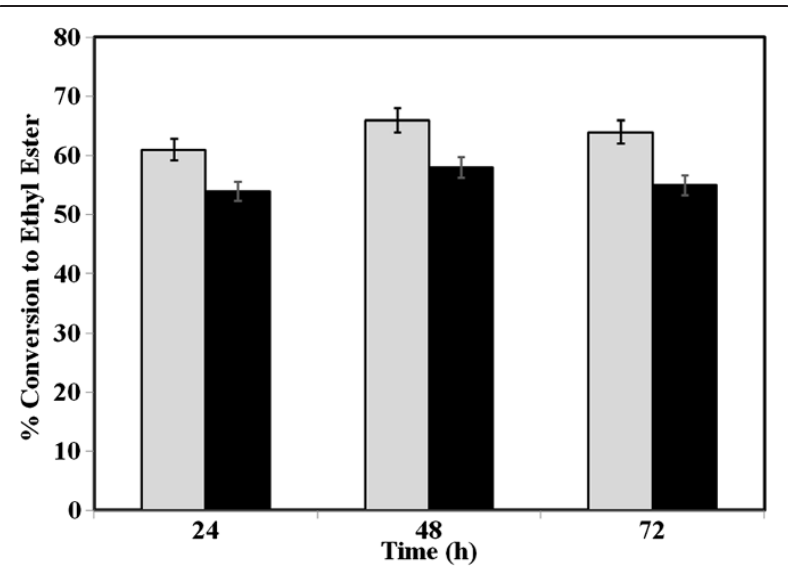

Figure 6 Preparation of biodiesel from Clean Coffee oil catalysed by PCMCs of CAL B (Grey Bars) and Palatase Black Bars). PCMC was made as described in materials and methods section. Reactions were performed taking $0.5 \mathrm{~g}$ coffee oil. Ethanol was added in molar ratio 4:1 (ethanol: oil). Conversion rates were measured by analyzing the aliquots withdrawn at the different time intervals using Gas Chromatographic analysis. The experiments were done in duplicates and the error between the two sets was within 3\%.

amounts (than used in the preparation of individual PCMCs) of CAL B and Palatase each were mixed and co-precipitated alongwith $\mathrm{K}_{2} \mathrm{SO}_{4}$ to form the combi-PCMC of CAL B and Palatase. This was found to perform significantly better than the corresponding mixture of PCMCs

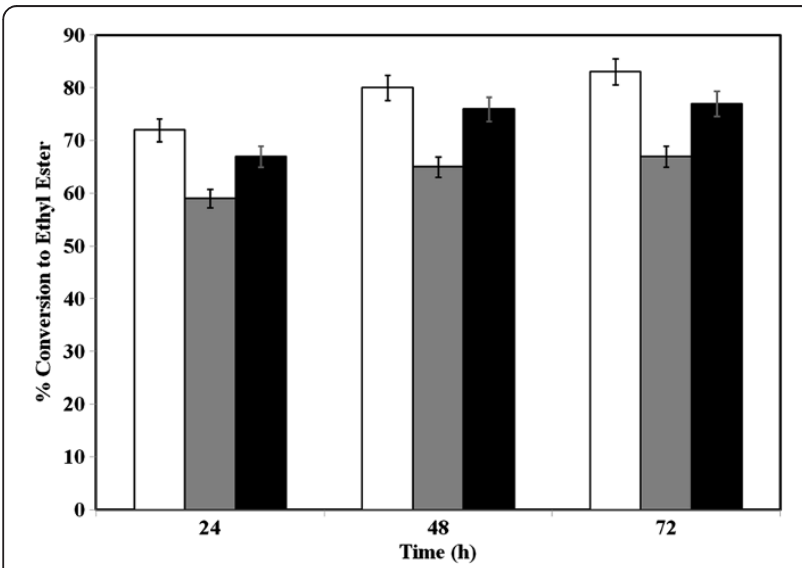

Figure 7 Biodiesel from Clean Coffee oil catalysed by Combi-PCMC (White Bars); a mixture of PCMCs (1:1) (Grey Bars) and CL-Combi-PCMC (Black Bars) of CAL B and Palatase (tert- Butanol used for precipitation). Reactions were performed taking $0.5 \mathrm{~g}$ coffee oil. Combi-PCMCs and CL-Combi-PCMCs were made as described in the materials and methods section. For a mixture of PCMCs, the individual PCMCs were made separately as mentioned in Figure 6 and then they were mixed in the ratio 1:1. Ethanol was added in molar ratio 4:1 (ethanol: oil). Conversion rates were measured by analyzing the aliquots withdrawn at the different time intervals using Gas Chromatographic analysis. The experiments were done in duplicates and the error between the two sets was within $3 \%$.
(Figure 7). The SEM image of Combi-PCMC is shown in Figure 8. Earlier we had reported that a crosslinked PCMC gave better transesterification rates as compared to PCMC [62]. In the combi-PCMC design, the crosslinking unfortunately did not yield a more efficient biocatalyst for biodiesel synthesis (Figure 7).

\section{Experimental \\ Materials}

Spent coffee grounds were obtained from the local outlet of a chain of coffee cafeterias Cafe Coffee Day. The vendor uses a mixture of Arabica (Coffea arabica) and Robusta (Coffea canephora) coffee seeds and this was used as a starting material for extracting oil. Lipases from Pseudomonas cepacia [PS, PS C (lipase immobilized on ceramic particle), PS D (lipase immobilized on diatomaceous earth)], Candida rugosa (lipase AY), Lipase from Mucor javanicus: Lipase M; Lipase from Aspergillus niger: Lipase AP12; Lipase from Penicillium camemberti: Lipase G were kind gifts from Amano Enzymes (Nagoya, Japan). Lipase B from Candida antarctica (CAL B), Rhizomucor miehei (Palatase), Novozym 435 (immobilized form of CAL B), Rhizomucor miehei lipase immobilized on macroporous anion exchange resin (Lipozyme RMIM) were kind gifts from Novozymes, (Denmark). Ethanol was purchased from Merck (Germany) and $n$-hexane was purchased from Sigma Aldrich (St. Louis, USA). All the alcohols and solvents were further dried by keeping overnight over $3 \AA$ molecular sieves bought from Merck (Mumbai, India).

\section{Soxhlet extraction of oil from spent coffee grounds}

Spent coffee grounds (50 g) were weighed in filter paper and placed in a $500 \mathrm{~mL}$ soxhlet glass timble. The extraction was carried out using $\mathrm{n}$-hexane as solvent $(380 \mathrm{~mL})$ at $70^{\circ} \mathrm{C}$. After extraction, the solvent was evaporated on a rotatory evaporator to obtain the coffee oil.

\section{Hexane extraction}

Spent coffee grounds $(50 \mathrm{~g})$ were added to hexane (400 $\mathrm{mL}$ ) taken in a $1 \mathrm{~L}$ round bottomed flask and it was refluxed for $4 \mathrm{~h}$. The hexane extract was filtered to remove the spent coffee grounds. The coffee oil was obtained from the filtered hexane extract by evaporating off the hexane in a rotatory evaporator.

\section{Three phase partitioning (TPP) for oil extraction}

Spent coffee grounds dispersed in water was mixed with $50 \%$ ammonium sulphate (w/v). tert-Butanol to aqueous layer was in a 1:1 ratio. It was then incubated for $1 \mathrm{~h}$ at $25^{\circ} \mathrm{C}$. After $1 \mathrm{~h}$ the mixture was centrifuged at $6000 \mathrm{x} \mathrm{g}$ for 15 minutes at $25^{\circ} \mathrm{C}$. The upper tert-butanol layer was then collected and dried using sodium sulphate. After drying the tert-butanol layer was evaporated on the rotary 

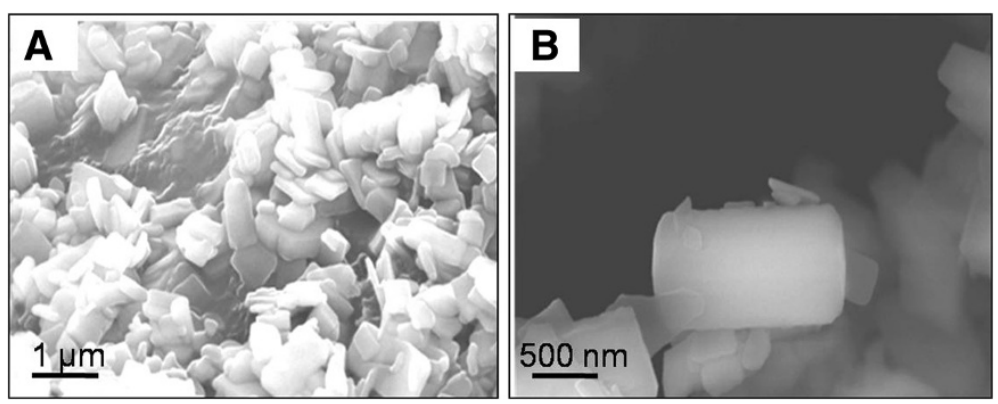

Figure $8 \mathrm{SEM}$ images showing (A) the $\mathrm{K}_{2} \mathrm{SO}_{4}$ crystals and (B) the Combi-PCMCs of Palatase and CAL B prepared using $\mathrm{K}_{2} \mathrm{SO}_{4}$ as the core material.

evaporator to remove the tert-butanol and obtain the coffee oil.

\section{Decolourization of coffee oil}

The coffee oil obtained by soxhlet extraction was refluxed with $2 \mathrm{~g}$ of activated charcoal at $70^{\circ} \mathrm{C}$ for half an hour. The hexane layer was then filtered to remove the activated charcoal. The clear hexane layer obtained after filtration was then evaporated in a rotary evaporator to remove the hexane and decolorized coffee oil was obtained.

\section{Preparation of protein coated microcrystals (PCMCs) of the enzyme}

PCMCs of CAL B and Palatase were prepared by starting directly from the liquid commercial preparations available from Novozyme, Denmark. The preparation of PCMCs was carried out essentially as described earlier [10]. The activities of CAL B and Palatase preparations used in the present work were $6 \mathrm{U} / \mathrm{mL}$ and $125 \mathrm{U} / \mathrm{mL}$ respectively. The activity unit corresponded to the assay based upon hydrolysis of $p$-nitrophenyl palmitate $[69,70]$. The corresponding protein contents were found to be $8.1 \mathrm{mg} / \mathrm{mL}$ and $6.8 \mathrm{mg} / \mathrm{mL}$ respectively as established by the dye binding assay [71]. $100 \mu \mathrm{L}$ of the enzyme was added to $100 \mu \mathrm{L}$ of $10 \mathrm{mM}$ sodium phosphate buffer $\mathrm{pH}$ 7.0. This solution was then added to $600 \mu \mathrm{L}$ of a saturated solution of potassium sulphate. The resulting solution was added dropwise to $6 \mathrm{~mL}$ of ice chilled tert-butanol at $4^{\circ} \mathrm{C}$ with constant shaking followed by incubation at $4^{\circ} \mathrm{C}$ with a constant shaking at $200 \mathrm{rpm}$ for $30 \mathrm{~min}$. After completion of $30 \mathrm{~min}$, the solution was first washed twice with tertbutanol and then once with acetone.

\section{Preparation of combi-protein coated microcrystals (Combi- PCMCs) of Palatase and CAL B}

Palatase $(50 \mu \mathrm{L})$ and CAL B $(50 \mu \mathrm{L})$ were added to $100 \mu \mathrm{L}$ of $10 \mathrm{mM}$ sodium phosphate buffer $\mathrm{pH}$ 7.0. This solution was then added to $600 \mu \mathrm{L}$ saturated solution of potassium sulphate. The resulting solution was added drop-wise to tert-butanol at $4^{\circ} \mathrm{C}$ with constant shaking. The resulting solution was the incubated at $4^{\circ} \mathrm{C}$ with constant shaking of $200 \mathrm{rpm}$ for $30 \mathrm{~min}$. After completion of $30 \mathrm{~min}$ the solution was first washed with tert-butanol twice and then once with acetone.

\section{Preparation of crosslinked combi protein coated microcrystals (CL-Combi-PCMCs)}

The Combi-PCMCs obtained above were dispersed in 1 $\mathrm{mL}$ of tert-butanol. The Combi-PCMCs were crosslinked by incubating with $50 \mathrm{mM}$ glutaraldehyde at $4^{\circ} \mathrm{C}$ with shaking at $300 \mathrm{rpm}$ for $4 \mathrm{~h}$. Combi-PCMCs thus obtained were washed twice with tert-butanol and then once with acetone.

\section{Synthesis of biodiesel}

Coffee oil $(0.5 \mathrm{~g})$ was mixed with ethanol $(126 \mu \mathrm{L})$ in $4: 1$ molar ratio of ethanol: oil. The enzyme preparation was added to the reactant mixture followed by incubation at $40^{\circ} \mathrm{C}$ with shaking at $200 \mathrm{rpm}$. Aliquots were taken at different time intervals and the percentage conversion to ethyl ester was determined by carrying out the GC analysis of the samples.

\section{GC analysis for biodiesel}

The alkyl esters were analyzed on Agilent Technologies $6890 \mathrm{~N}$ network GC systems, USA with a flame ionization detector. The standard reference method EN 14103 was used [72]. The capillary column HP- 5 (5\% diphenyl 95\% dimethylpolysiloxane), $30 \mathrm{~m} \mathrm{X} 0.32 \mathrm{~mm}$ X $0.25 \mu \mathrm{m}$ (Agilent) was used. Nitrogen was used as the carrier gas. The column oven temperature was programmed in the range of $150^{\circ} \mathrm{C}$ to $250^{\circ} \mathrm{C}$ at $10^{\circ} \mathrm{C} \mathrm{min}{ }^{-1}$ with injector and detector temperatures at $240^{\circ} \mathrm{C}$ and $250^{\circ} \mathrm{C}$, respectively.

The resulting fatty acid esters (biodiesel) from the reaction were weighed and mixed with the internal standard methyl heptadecanoate $(10 \mathrm{mg} / \mathrm{ml}$ solution in hexane). The final concentration of sample in the mixture is $50 \mathrm{mg} / \mathrm{ml} .1 \mu \mathrm{l}$ of this mixture was injected in the GC. Peak areas of fatty acid esters and internal standard were obtained. 
Result for the fatty acid ester content is expressed as a mass fraction in percent using methyl heptadecanoate $C_{17}$ as the internal standard by using the following formula:

$$
c=\frac{\sum A-A^{\prime}}{A^{\prime}} \times \frac{C^{\prime} \times V^{\prime}}{m} \times 100 \%
$$

Where:

$\Sigma A=$ total peak area C14:0 - C24:1

$A^{\prime}=$ internal standard peak area (methyl heptadecanoate)

$C^{\prime}=$ concentration of internal standard solution in $\mathrm{mg} / \mathrm{mL}$

$\mathrm{V}^{\prime}$ = volume of internal standard solution used in $\mathrm{mL}$

$\mathrm{m}=$ mass of the sample in $\mathrm{mg}$

Similar quantification approach for biodiesel preparation has been used by earlier workers $[73,74]$.

\section{Conclusions}

To sum up, coffee oil extracted from spent coffee grounds could be used for the synthesis of biodiesel by using appropriate commercial preparations of lipases. The expensive commercially immobilized preparations can also be replaced by a simpler and inexpensive immobilization design called combi-PCMC which synergizes the catalytic action of a nonspecific lipase CAL B and a free form of 1,3-specific lipase from Rhizomucor miehei.

The preparation of biodiesel employed a waste material as an oil source. The coffee plant itself is a renewable resource. The biocatalyst design used a simple salt as the immobilization matrix. Hence, the process constitutes a sustainable as well as an inexpensive approach for biodiesel synthesis.

\section{Additional file}

Additional file 1: Figure S1. Effect of enzyme load. Crude coffee oil $(0.5 \mathrm{~g})$ and ethanol were taken in the molar ratio of 1:4. 5\% and 10\% (w/W of oil) Novozym 435 lipase was added and incubated at $40^{\circ} \mathrm{C}$. Aliquots were taken out at regular intervals and analyzed by GC as described in materials and methods section. The experiments were done in duplicates and the error between the two sets was within $3 \%$.

\section{Competing interests}

The authors declare that they have no competing interests.

\section{Authors' contributions}

MNG proposed the subject, designed the study, participated in the scientific discussions, interpretation of the results and drafted the manuscript. AB, VS, $\mathrm{KS}$ and JM carried out the experimental work. All authors read and approved the final manuscript.

\section{Acknowledgements}

JM thanks the Council of Scientific and Industrial Research for the Senior Research Fellowship. Funds obtained from the Government of India's Department of Science and Technology (DST) [Grant No.: SR/SO/BB-68/2010] and Department of Biotechnology (DBT) [Grant No.: BT/PR14103/BRB/10/808/ 2010] are gratefully acknowledged.

\section{Author details}

'Department of Chemistry, University of Illinois Urbana Champaign, Urbana, Illinois, USA. 'Department of Chemistry, Indian Institute of Technology Delhi, Hauz Khas, New Delhi 110016, India. ${ }^{3}$ Center for Biotechnology and
Interdisciplinary Studies, Rensselaer Polytechnic Institute, Troy, NY, USA. ${ }^{4}$ Department of Biochemical Engineering and Biotechnology, Indian Institute of Technology Delhi, Hauz Khas, New Delhi 110016, India.

Received: 12 May 2013 Accepted: 5 August 2013

Published: 8 August 2013

\section{References}

1. Straathof AJJ: Adlercreutz P (Eds): Applied Biocatalysis. London: Taylor and Francis; 2000.

2. Schoemaker HE, Mink D, Wubbolts MG: Dispelling the myths- biocatalysis in industrial synthesis. Science 2003, 299:1694-1697.

3. Kapoor M, Gupta MN: Lipase Promiscuity and its biochemical applications. Process Biochem 2012, 47:555-569.

4. Linfield WM, O'Brien DJ, Serota S, Barauskas RA: Lipid- lipase interactions. I. Fat splitting with lipase from Candida rugosa. J Am Oil Chem Soc 1984, 61:1067-1071.

5. Vulfson EN, Halling PJ: Holland HL (Eds): Enzymes In Nonaqueous Solvents. New Jersey: Humana Press Inc:; 2001.

6. Adlercreutz P: Immobilisation and application of lipases in organic media. Chem Soc Rev 2013, 42:6406-6436.

7. Lee MY, Dordick JS: Enzyme activation for non-aqueous media. Curr Opin Biotechnol 2002, 13:376-384.

8. Hudson EP, Eppler RK, Clark DS: Biocatalysis in semi-aqueous and nearly anhydrous conditions. Curr Opin Biotechnol 2005, 16:637-643.

9. Clair NLS, Navia MA: Crosslinked enzyme crystals as robust biocatalyst. J Am Chem Soc 1992, 114:7314-7316.

10. Kreiner M, Moore BD, Parker MC: Enzyme-coated micro-crystals: a 1-step method for high activity biocatalyst preparation. Chem Commun 2001:1096-1097.

11. Lopez-Serrano P, Cao L, Van Rantwijk F, Sheldon RA: Cross-linked enzyme aggregates with enhanced activity: application to lipases. Biotechnol Lett 2002, 24:1379-1383.

12. Sheldon RA, Schoevaart R, Van Langen LM: Crosslinked enzyme aggregates (CLEAs): A novel and versatile method for enzyme immobilization (a review). Biocatal Biotransform 2005, 23:141-147.

13. Shah S, Sharma A, Gupta MN: Preparation of cross-linked enzyme aggregates by using bovine serum albumin as a proteic feeder. Anal Biochem 2006, 351:207-213.

14. Shah S, Sharma A, Varandani D, Mehta BR, Gupta MN: A high performance lipase preparation: Characterization and atomic force microscopy. J Nanosci Nanotechnol 2007, 7:1-4.

15. Majumder AB, Gupta MN: Increasing catalytic efficiency of Candida rugosa lipase for the synthesis of tert-alkyl butyrates in low-water media. Biocatal Biotransform 2011, 29:238-245.

16. Kreiner M, Parker MC: Protein-coated micro crystals for use in organic solvents: application to oxidoreductases. Biotechnol Lett 2005, 27:1571-1577.

17. Hernández-Martín $E$, Otero C: Different enzyme requirements for the synthesis of biodiesel: Novozym ${ }^{\oplus} 435$ and Lipozyme ${ }^{\oplus}$ TL IM. Bioresour Technol 2008, 99:277-286.

18. Rodrigues RC, Fernandez-Lafuente R: Lipase from Rhizomucor miehei as an industrial biocatalyst in chemical process. J Mol Catal B: Enz 2010, 64:1-22.

19. Mittelbach M, Remschmidt C: Biodiesel: The comprehensive handbook. M. Mittelbach, Graz: First Edition; 2004.

20. Shah S, Sharma S, Gupta MN: Biodiesel preparation by lipase catalyzed transesterification of Jatropha oil. Energy Fuels 2004, 40:1077-1082.

21. Jegannathan KR, Abang S, Poncelet D, Chan ES, Ravindra P: Production of biodiesel using immobilized lipase- a critical review. Crit Rev Biotechnol 2008, 28:253-264.

22. Robles- Medina A, González- Moreno PA, Esteban- Cerdán L, Molina- Grima E: Biocatalysis: Towards ever greener biodiesel production. Biotechnol Adv 2009, 27:398-408.

23. Antczak MS, Kubiak A, Antczak T, Bielecki S: Enzymatic biodiesel synthesis - key factors affecting efficiency of the process. Renew Energy 2009, 34:1185-1194.

24. Demirbas A: Biodiesel from waste cooking oil via base-catalytic and supercritical methanol transesterification. Energy Convers Mgmt 2009, 50:923-927.

25. Tan T, Lu J, Nie K, Deng L, Wang F: Biodiesel production with immobilized lipase: A review. Biotechnol Adv 2010, 28:628-634.

26. Zanette AF, Barellla RA, Pergher SBC, Treichel- Oliveira HD, Mazutti MA, Silva EA, Oliviera JV: Screening, optimization and kinetics of Jatropha curcas oil 
transesterification with heterogeneous catalysts. Renew Energy 2011, 36:726-731.

27. Bernal JM, Lozano P, García-Verdugo E, Isabel Burguete M, Sánchez-Gómez G, López-López G, Pucheault M, Vaultier M, Luis SV: Supercritical synthesis of biodiesel. Molecules 2012, 17:8696-8719.

28. Dacquin JP, Lee AF, Pireza C, Wilson K: Pore-expanded SBA-15 sulfonic acid silicas for biodiesel synthesis. Chem Commun 2012, 48:212-214.

29. Abduh MY, Van Ulden W, Kalpoe V, Van deBovenkamp HH, Manurung R, Heeres HJ: Biodiesel synthesis from Jatropha curcas L. oil and ethanol in a continuous centrifugal contactor separator. Eur J Lipid Sci Technol 2013, 115:123-131.

30. Zhao H, Baker GA: Ionic liquids and deep eutectic solvents for biodiesel synthesis: a review. J Chem Technol Biotechnol 2013, 88:3-12.

31. Dale BE: A level playing field for biofuels and bioproducts. Biofuel Bioprod Bioref 2008, 2:1-2.

32. Hsu AF, Jones K, Foglia TA: Immobilized lipase catalyzed production of alkyl esters of restaurant grease as a biodiesel. Biotechnol Appl Biochem 2002, 36:181-186.

33. Yuan X, Liu J, Zeng G, Shi J, Tong J, Huang G: Optimization of conversion of waste rapeseed oil with high FFA to biodiesel using surface response methodology. Renew Energy 2008, 33:1678-1684.

34. Enweremadu CC, Mbarawa MM: Technical aspects of production and analysis of biodiesel from used cooking oil- A review. Renew Sus Energy Rev 2009, 13:2205-2224.

35. Oliveira LS, Franca AS, Camargos RRS, Ferraz VP: Coffee oil as a potential feedstock for biodiesel production. Bioresour Technol 2008, 99:3244-3250.

36. Kondamudi N, Mohapatra SK, Misra M: Spent coffee grounds as a versatile source of green energy. J Agric Food Chem 2008, 56:11757-11760.

37. Calixto F, Fernades J, Couto R, Hernández EJ, Najdanovic- Visak V, Simoes PC: Synthesis of fatty acid methyl esters via direct transesterification with methanol/ carbon dioxide mixtures from spent coffee grounds feedstock. Green Chem 2011, 13:1196-1202.

38. Araújo JMA, Sandi D: Extraction of coffee diterpenes and coffee oil using supercritical carbon dioxide. Food Chem 2006, 101:1087-1094.

39. Nelson LA, Foglia TA, Marmer WN: Lipase-catalysed production of biodiesel. J Am Oil Chem Soc 1996, 73:1191-1195.

40. Fukuda $\mathrm{H}$, Kondo A, Noda H: Biodiesel fuel production by transesterification of oils. J Biosci Bioeng 2001, 92:405-416.

41. Du W, Xu Y, Liu D, Zeng J: Improved methanol tolerance during Novozyme 435-mediated methanolysis of SODD for biodiesel production. J Mol Catal B Enzym 2004, 30:125-129.

42. Shah S, Gupta MN: Lipase catalyzed preparation of biodiesel from Jatropha oil in a solvent free system. Process Biochem 2007, 42:409-414.

43. Kumari V, Shah S, Gupta MN: Preparation of biodiesel by lipase catalyzed transesterification of high free fatty acid containing oil from Madhuca indica. Energy Fuels 2007, 21:368-372.

44. Singh V, Solanki K, Gupta MN: Process optimization for biodiesel production. Recent Patent Biotechnol 2008, 2:130-143.

45. Tongboriboon K, Cheirsilp B, Kittikun AH: Mixed lipases for efficient enzymatic synthesis of biodiesel from used palm oil and ethanol in a solvent-free system. J Mol Catal B Enzym 2010, 67:52-59.

46. Mendes AA, Oliveira PC, Vélez AM, Giordano RC, Giordano RL, De Castro HF: Evaluation of immobilized lipases on poly-hydroxybutyrate beads to catalyze biodiesel synthesis. Int J Biol Macromol 2012, 50:503-511.

47. Gupta MN: Enzyme function in organic solvents. Eur J Biochem 1992, 203:25-32.

48. Carrea G, Riva S: Properties and synthetic applications of enzymes in organic solvents. Angew Chem Int Ed 2000, 39:2226-2254.

49. Daglia M, Racchi M, Papetti A, Lanni C, Govoni S, Gazzani G: In vitro and ex vivo antihydroxyl radical activity of green and roasted coffee. J Agri Food Chem 2004, 52:1700-1704.

50. Sharma A, Khare SK, Gupta MN: Three phase partitioning for extraction of oil from soybean. Bioresour Technol 2002, 85:327-329.

51. Halling PJ: Thermodyanamic predictions for biocatalysis in nonconventional media: Theory, tests, and recommendations for experimental design and analysis. Enzyme Microb Technol 1994, 16:178-206.

52. Pirrozi D, Greco G Jr: Activity and stability of lipases in the synthesis of butyl lactate. Enzyme Microb Technol 2004, 34:94-100.

53. Shimada Y, Watanabe $Y$, Samukawa T, Sugihara A, Noda H, Fukuda H, Tominaga Y: Conversion of vegetable oil to biodiesel using immobilized Candida antarctica lipase. J Am Oil Chem Soc 1999, 76:789-792.
54. Watanabe Y, Shimada Y, Sugihara A, Noda H, Fukuda H, Tominaga Y: Continuous production of biodiesel fuel from vegetable oil using immobilized Candida antarctica lipase. J Am Oil Chem Soc 2000, 77:355-360.

55. Belafi-Bako K, Kovacs F, Gubicza L, Hancsok J: Enzymatic Biodiesel Production from Sunflower Oil by Candida antarctica Lipase in a Solvent-free System. Biocatal Biotransform 2002, 20:437-439.

56. Halling PJ: What can we learn by studying enzymes in non-aqueous media? Phil Trans R Soc Lond B 2004, 359:1287-1297.

57. Chang HM, Liao HF, Lee CC, Shieh CJ: Optimized synthesis of lipase-catalyzed biodiesel by Novozym 435. J Chem Technol Biotechnol 2005, 80:307-312.

58. Royon D, Daz M, Ellenrieder G, Locatelli S: Enzymatic production of biodiesel from cotton seed oil using t-butanol as a solvent. Bioresour Technol 2007, 98:648-653.

59. Sjursnes BJ, Anthonsen T: Acyl migration in 1,2-dibutyrin dependence on solvent and water activity. Biocatal Biotransform 1994, 9:285-297.

60. Sjursnes BJ, Kvittingen L, Anthonsen T: Regioselective lipase catalyzed transesterification of tributyrin: Influence of salt hydrates on acyl migration. J Am Oil Chem Soc 1995, 92:533-537.

61. Govardhan CP: Crosslinking of enzymes for improved stability and performance. Curr Opin Biotechnol 1999, 10:331-335.

62. Shah S, Sharma A, Gupta MN: Cross-linked protein coated microcrystals as biocatalysts in non-aqueous solvents. Biocatal Biotransform 2008, 26:266-271.

63. Sheldon RA: Characteristic features and biotechnological applications of cross-linked enzyme aggregates (CLEAs). Appl Microbiol Biotechnol 2011, 92:467-477

64. Schoevaart R, Wolbers MW, Golubovic M, Ottens M, Kieboom APG, Van Rantwijk F, Van der Wielen LAM, Sheldon RA: Preparation, optimization, and structures of cross-linked enzyme aggregates (CLEAs). Biotechnol Bioeng 2004, 87:754-762

65. Mosbach K, Mattiasson B: Multistep enzyme systems. In Methods in Enzymology. Vol XLIVth edition. Edited by Mosbach K. New York: Academic Press; 1976:453-478.

66. Roy I, Gupta MN: Hydrolysis of starch by a mixture of glucoamylase and pullulanase entrapped individually in calcium alginate beads. Enzym Microb Technol 2004, 34:26-32.

67. Dalal S, Kapoor M, Gupta MN: Preparation and characterization of combi-CLEAs catalyzing multiple non-cascade reactions. J Mol Catal B Enzym 2007, 44:128-132.

68. Dalal S, Sharma A, Gupta MN: A multipurpose immobilized biocatalyst with pectinase, xylanase and cellulase activities. Chem Cent J 2007, 1:16-19.

69. Kilcawley KN, Wilkinson MG, Fox PF: Determination of key enzyme activities in commercial peptidase and lipase preparations from microbial or animal sources. Enzym Microb Technol 2002, 31:310-320.

70. Jain P, Jain S, Gupta MN: A microwave assisted microassay for lipase. Anal Bioanal Chem 2005, 381:1480-1482.

71. Bradford MM: A Rapid and Sensitive Method for the Quantitation of Microgram Quantities of Protein Utilizing the Principle of Protein-Dye Binding. Anal Biochem 1976, 72:248-254.

72. Ruppel T, Huybrighs T: Fatty acid methyl esters in B100 biodiesel by gas chromatography (Modified EN14103). Shelton CT, USA: Perkin Elmer, Inc; 2008.

73. Liu Y, Wang L: Biodiesel production from rapeseed deodorizer distillate in a packed column reactor. Chem Eng Process: Process Intens 2009, 48:1152-1156

74. Liu Y, Tan H, Zhang X, Yan Y, Hameed BH: Effect of monohydric alcohols on enzymatic transesterification for biodiesel production. Chem Eng J 2010, 157:223-229.

doi:10.1186/2043-7129-1-14

Cite this article as: Banerjee et al:: Combi-protein coated microcrystals of lipases for production of biodiesel from oil from spent coffee grounds. Sustainable Chemical Processes 2013 1:14. 